\title{
ACTIVE VIBRATION ABSORBER FOR CSI EVOLUTIONARY MODEL: DESIGN AND EXPERIMENTAL RESULTS
}

Anne M. Bruner, W. Keith Belvin, Lucas G. Horta, and Jer-Nan Juang

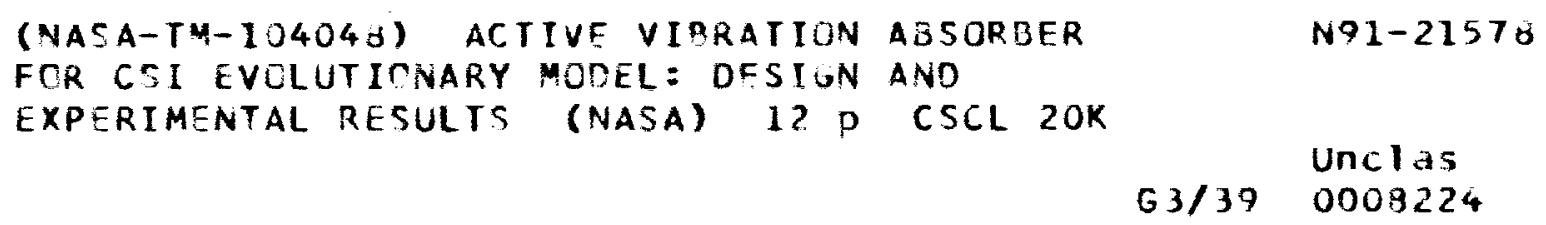

March 1991

\section{NกSก}

National Aeronautics and Space Administration Langley Research Center Hampton, Virginia 23665 


\title{
ACTIVE VIBRATION ABSORBER FOR THE CSI EVOLUTIONARY MODEL: DESIGN AND EXPERIMENTAL RESULTS
}

\author{
Anne M. Brunce* \\ lockheed Engincering and Sciences Company \\ Hampion, Virginia \\ W. Keith Bclvin', Lucas G. Horta' and Jer-Nan Juang ** \\ NASA Langley Rescanch Center \\ Hampten, Virginia
}

\begin{abstract}
The development of control of large flexible structures technology must include practical demonstrations to aid in the understanding and characterization of controlled structures in space. To support this effort, a testbed racility has been developed to sludy practical implementation of new control lechnologics under realistic conditions. The paper discusses the design of a second order, acceleration fecdback controller which acts as an active vibration absorber. This controller provides guaranteed stability margins for collocated sensor/actuator pairs in the absence of sensor/actuator dynamics and computational time delay. Experimental results in the presence of these factors are presented and discussed. The primary performance objeclive considered is damping augmentation of the first nine slfucluril modes. Comparison of experimental and predicted closed-loop damping is presented, including test and simulated time histories for open and closed-loop cases. Although the simulation and test results are not in fult agreement, robustiness of this design under mokel uncertainty is demonstraled. The basic advantage of this secondorder controller design is that the stability of the controller is mordel independent.
\end{abstract}

\section{Introduction}

I.arge space structure control requires special control design methodology. High modal density in the controller bandwidth makes rolloff of control authority a problem.

\footnotetext{
- Structural Control Engincer, Lockhecd Engincering and Scicnces Company, Hamplon, VA.

I Acrospace Engincer, Struclural Dynamics Branch, Mcmber AIAA.

- Principal Scientist, Structural Dynamics Branch, Associale Fellow AIAA.
}

Many of the theoretical issues with regard to large space structure control were recognized and initially teated by Benhabid, Flashner, and Tung.' Experimentil validation is now being demonstrated with a series of facilitics which have been designed for that purpose. ${ }^{2,3,4}$ II is recognized that the complexity of these structures foster the use of controllers with high and low authority. Theorctically, low authority controllers are used to augment the inherent damping of the structurc, while the high authority controllers arc designed to achieve the desired performance. One form of these low authority controllers is an active vibration absorber (AVA), which is the subject of this paper.

NASA and the Controls Structures Intcraction (CSI) program have undertaken the design, development, and fabrication of gencric structures to study fundamental problems in the implementation of advancel control methodologics. The program stresses the application of existing sensor and actuator tochnologies for identification and control. The first such testbed of the CSI program has been completed at the NASA Langley Rescarch Center. The configuration sclected, which is descriled in detail in a later section, uses thrusters and accelerometers as its primary actuation and sensing devices. Initially, controller designs that would not require knowlcdge of the dynamics of the structure are preferred. This allows the implementation of such controlkers even when model uncertainties are large. For this purpose, a procedure for designing second order controllers using passitivity concepts is discussed for continuous time systems. ${ }^{8}$ Using this approach, decentralized controllers have been designed and used for experimental validation.

The paper outline is as follows: first the controller design theory is presented followed by a mechanical analogy. A brief description of the testbed is given, and a controller design procedure for the laboratory model is described. Finally, test results from the cxperimental implementation are provided and compared with the analytical results. 


\section{Controller Design Theory}

For large scale systems, a model of the stnucture is often obtained vin finite clement methods resulting in a set of state and output equations of the form:

$$
\begin{aligned}
& M \bar{z}+D \pm+K z=B_{u} \\
& y=H_{a} \bar{z}+H_{u} t+H_{d z}
\end{aligned}
$$

Here $z$ is an $n \times 1$ statc vector, and $M, D$, and $K$ are mass, damping, and stilfness matrices, respectively, which generally are symmetric and sparse. The $n \times p$ influence matrix $n$ :Iescribes the actuator fonce distributions for the $p \times 1$ inr ut vector $u$. Equation (2) is a measurement cquation with $y$ as the $m \times 1$ measurement vector, $H_{a}$ the $m \times n$ accolcration infuence matrix, $H_{v}$ the $m \times n$ velocily influence inatrix, and $H_{d}$ the $m \times n$ displacement influence matrix. Fir dircct output recdback control, the input vector u can be uritten

$$
t=-G y=-G H_{a} \bar{z}-G H_{v} \pm-G H_{d^{2}}
$$

where $G$ is a gain matrix to be detemined. Substituting Fq. (3) into Eq. (1) yiclds

$$
\left(M+B G I_{a}\right) \bar{x}+\left(D+B G H_{v}\right) \dot{x}+\left(K+B G H_{d}\right)=0
$$

It is shown by Juang arki Phan ${ }^{5}$ that for a structural systcm, oulput velocity fecdlsack with collocated sensors and ac luators makes the closcd-Ioop system asymptotically stable with an infinite gain margin. Withoul velocity sensors, however, the system damping cannot be augmented with direct output fecdback unless additional dynamics are inimaduced.

Let the controller to be designed have a set of secondorder dynamic cquations and measurement equations similar to the system equations, Eqs. (1) and (2),

$$
\begin{aligned}
& M_{c} \bar{x}_{c}+D_{c} \dot{x}_{c}+K_{c} x_{c}=H_{c} \psi_{c} \\
& \eta_{c}=H_{a c} \bar{x}_{c}+H_{v c \dot{x}_{c}}+H_{d c} x_{c}
\end{aligned}
$$

Here $x_{c}$ is the controller state vector of dimension $n_{c}$. and $M_{c}, D_{c}$, and $K_{c}$ can be interpreted as the controller inass, damping, and stiffncss matrices, respectively, which in general, are symmetric and positive definite 10 make the controller asymplotically stable. The $n_{e} \times m$ infiuence $\mathrm{ma}$ trix $B_{e}$ describes Ihe force distributions for the $m \times 1$ input force vector uc. Fypution (6) is the controller measurement cefuation having $y_{c}$ as the measurement vector of length $p$. $H_{n e}$ the $p \times n_{e}$ acceleration influcnce matrix, $H_{v e}$ the $p \times n_{e}$ velocity infuence matrix, and $H_{d e}$ the $p \times n_{e}$ displacement infuence matrix. All the quantities $v_{e}, y_{e}$, and $n_{e}$, are arbitrary which means that $M_{c}, D_{c}, K_{c}, H_{d e}, H_{u c}, H_{a c}$ and $B_{e}$ are the design paramelers for the controlicr.
Let the input vector 4 in Fq. (1) and $u_{e}$ in Fq. (5) be

$$
\begin{gathered}
v=y_{c}=H_{a c} \bar{x}_{c}+H_{u c} \dot{t}_{c}+H_{d_{e}} x_{c} \\
u_{c}=y=H_{a} \bar{x}+H_{u} \dot{x}+H_{d} x
\end{gathered}
$$

Suhstituling Fq. (7) inlo F.. (1) and F.q. (8) into Fq. (5) yiclus

$$
M_{1} \tilde{x}_{t}+D_{l} \pm_{t}+K_{1} x_{t}=0
$$

where

$$
\begin{gathered}
M_{t}=\left[\begin{array}{cc}
M & -B H_{a c} \\
-B_{c} H_{a} & M_{c}
\end{array}\right], \\
D_{t}=\left[\begin{array}{cc}
D & -B H_{v e} \\
-B_{c} H_{v} & D_{c}
\end{array}\right], \\
K_{t}=\left[\begin{array}{cc}
K & -n H_{d c} \\
-B_{c} H_{d} & K_{c}
\end{array}\right], x_{t}=\left[\begin{array}{c}
x \\
x_{c}
\end{array}\right]
\end{gathered}
$$

If the design parameters are chosen such that $M_{t}, D_{t}$ and $K_{t}$ are positive definitc, the closed loop system, Eq. (9), becomes asymptotically stable.

Consider the special case for acceleration fecthack only where $H_{d}=H_{v}=H_{d c}=H_{v e}=0$ in Eq. (9). This makes the closod-loop mass, damping and stiffness matrices

$$
\begin{gathered}
M_{t}=\left[\begin{array}{cc}
M & -B H_{a c} \\
-B_{c} H_{a} & M_{c}
\end{array}\right], D_{t}=\left[\begin{array}{cc}
D & 0 \\
0 & D_{c}
\end{array}\right], \\
K_{t}=\left[\begin{array}{cc}
K & 0 \\
0 & K_{e}
\end{array}\right]
\end{gathered}
$$

For $M_{\ell}$ to be a positive Ilefinite matrix, it must be a real, symmetric matrix salisfying

$$
x_{i}^{T} M_{1} x_{1}>0
$$

for any real vector $x_{1}$ except the null vector. To make $M_{1}$ symmetric, it is requirct that

$$
B H_{a c}=H_{a}^{T} B_{e}^{T}
$$

Substituting the definition of $x_{t}$ and $M_{t}$ into $E q .(10)$ and using Eq. (11) yiclds

$$
\begin{gathered}
x_{t}^{T} M_{1} x_{l}=x^{T}\left(M-B H_{a c} H_{a c}^{T} B^{T}\right) x+ \\
\left(H_{a c}^{T} B^{T} x_{2} x_{c}\right)^{T}\left(H_{a c}^{T} B^{T}-x_{c}\right)+x_{c}^{T}\left(M_{c}-I\right) x_{c}
\end{gathered}
$$

This equation is greater than zcro if $H_{a c}$ and $M_{c}$ are chosen such that $M-B H_{a c} H_{a c}^{T} B^{T}$ and $M_{c}-I$ are positive definite. Note that this is a sufficient condition but not a necessary onc. 
In an attempe to wbiain a controlicr structure without lhis restriction on $H_{\text {ac }}$ and $M_{c}$. Ict the $u$ in Eq. (7) be modified to include a direct acceleration fecelback $\mathrm{tcm}$. Ihen

$$
u=V_{c}-G_{a y}=H_{a c} \hat{x}_{c}-G_{a y}
$$

which makes

$$
M_{t}=\left[\begin{array}{cc}
M+H i_{a} H_{a} & -n H_{a c} \\
-H_{c} H_{a} & M_{c}
\end{array}\right]
$$

Defining

$$
G_{a}=H_{a c} M_{c}^{-1} B_{c}
$$

substiluting into $\mathrm{F} q \mathrm{f}$ (13), and using the symmetry condition in Eq. (11), the positive definite condition in Eq. (10) ixcomes

$$
\begin{gathered}
x_{i}^{T} M_{t} x_{t}=x^{T} M_{2+} \\
\left(M_{c}^{-1} B_{c} H_{a x}-x_{c}\right)^{T} M_{c}\left(M_{c}^{-1} n_{c} H_{a} x-x_{c}\right)
\end{gathered}
$$

which is positive if $M$ and $M_{c}$ are pusitive definile matrices. Figure I shows a block diagram of the closal$I(x)$ ) syslcm with acceleration fecdhack. Figure 2 depicts a rediced block diagran for llic same sysicm. To design a sccond-order controller having the stnkiture given in $(5),(6),(8),(12)$, and (14), it is only mecessary to require

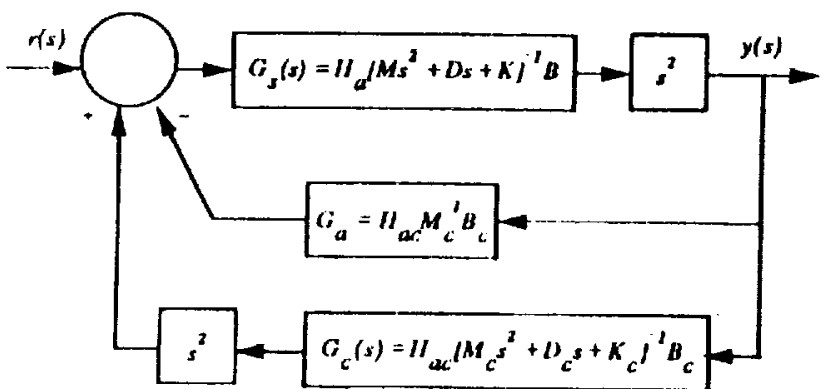

Fignre 1. Mlock dingram of ckssed loop systom witl, rlirect and dynamic forenllowk

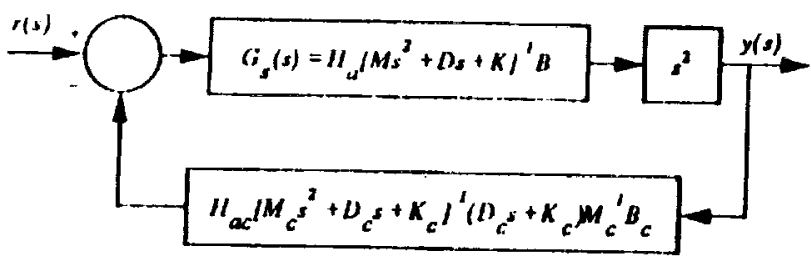

ligure 2. IRedured block diagram of closed-loop system with general accoleration fecellack
$M_{c}, D_{c}$ and $K_{c}$ to be prisitive definite and that Eq. (11) is satisficd.

\section{Mechanical Analogy}

With further constraints on the plant and controller, this secombl-orker controller can be thought of as allikhing an acklitional mass, spring and damper asscmbly to the structure at the lixation of the sensors/actuators. Fox the case of a single molc plant, a cliagram representing the closed-loop sysicm can the drawn as shown in Fig. 3. I.clling $x_{c}=x_{a}-x$ results in plant and controller cquations:

$$
\begin{gathered}
\text { Plant: } M \bar{x}+D \dot{x}+K z=z_{c} \\
y=\bar{z} \\
\text { Controller: } M_{c} \ddot{x}_{c}+D_{c} \dot{x}_{c} \mid K_{c z_{c}}-M_{c} y \\
z_{c}=K_{c} x_{c}-D_{c} \dot{x_{c}}
\end{gathered}
$$

A block diagram for lhis physical system is show' in Fig. 4. Upon comparison of lig. 2 and lig. 4, $H_{\text {ac }}$ and $B_{c}$ must satisfy

$$
H_{\mathrm{u} r} H_{c}=M_{\mathrm{r}}^{2}
$$

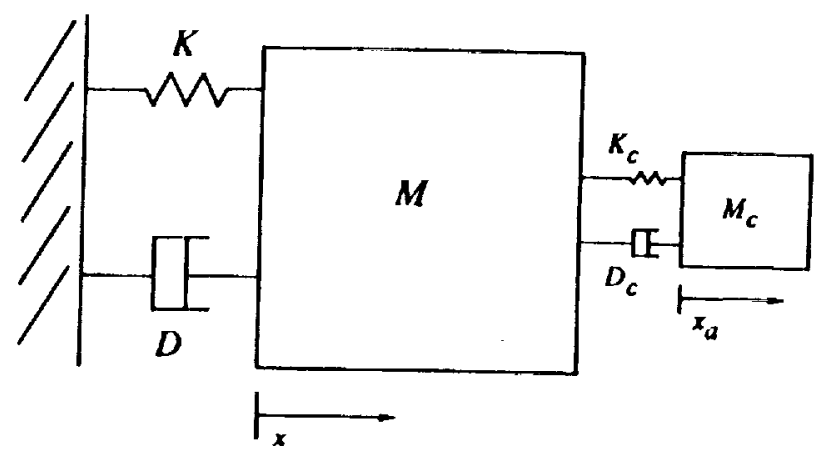

Figure 3. Single morle strurture-coutroller design III)

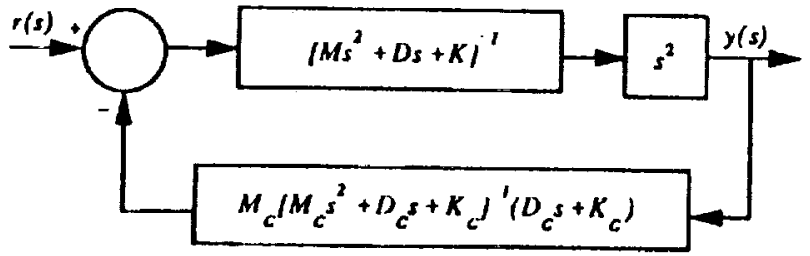

Figure 1. Block diagram of simgle morle structure controller closed-loop system 
Assuming collocalcd scnsors and actunions and unity force input, the constraints Riven in Eaps. (II) and (I8) dictute:

$$
\begin{gathered}
H_{a}=1 \\
n=1 \\
H_{a c}=M_{c} \\
n_{e}=M_{c}
\end{gathered}
$$

Using the controller equations given in Fq. (17), a state space model can be written:

$$
\begin{aligned}
& \dot{\bar{x}}=A \bar{x}+B_{y} \\
& u-C \bar{x}+D_{y}
\end{aligned}
$$

where.

$$
\begin{aligned}
& A-\left[\begin{array}{cc}
n & 1 \\
K_{e} / M_{e} & \ldots D_{e} / M_{e}
\end{array}\right], n-\left[\begin{array}{l}
n \\
1
\end{array}\right], \\
& \left.C=\left|-K_{e}-D_{e}\right|, \quad D=\mid 0\right], \quad \bar{x}=\left[\begin{array}{l}
x_{e} \\
i_{e}
\end{array}\right]
\end{aligned}
$$

The contunller low frequency gain cuunls $\boldsymbol{M}_{\mathrm{e}}$. In the prescuce of schsor bias, a large $M_{e}$ could result in large aclintor command offscts or even saluration. It is important Io sclect conservative valucs for $M_{c}$ to reduce the ertects if ofiscts. In analogy with vibration absorbers ${ }^{\circ}$, the frefuency of the absorher is sct equal to the targeted moxle. i.c. $u^{2}=K_{c} / \boldsymbol{M}_{c}$. After selecting values for $\mathcal{M}_{c}$ and $K_{e}$, valuc: for $D_{c}$ arc selected hased on roxt licus design. In

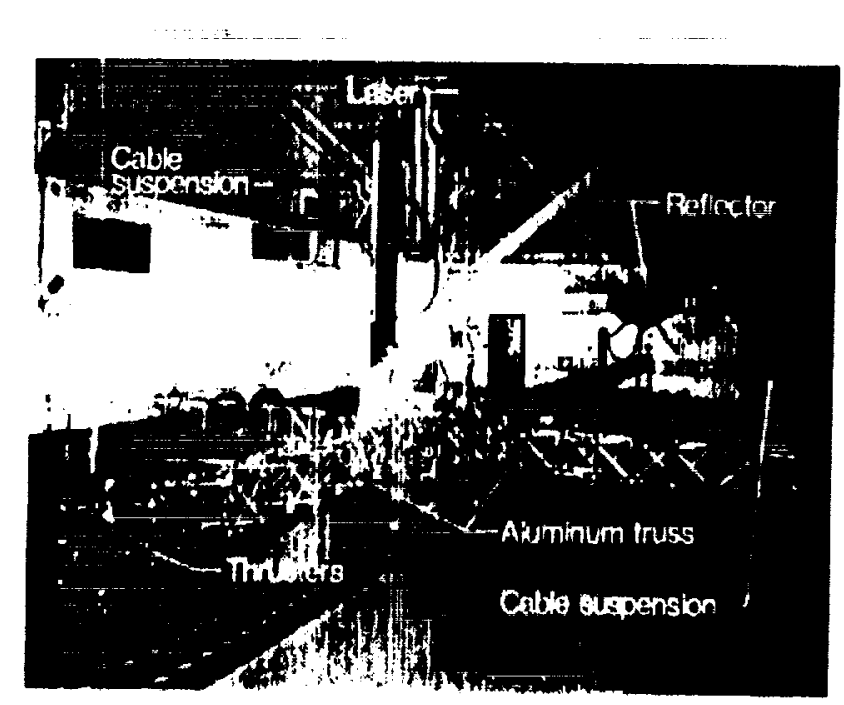

Figure 5. Photograylu of Ihe (SSl fivolutinnary Model tresthed the following scction, a description of the Iesthed facilily is presenial.

\section{Laboratory Model Description}

A photogmph of the cuolutionary mokel tcsiled [4] is shown in Fig. 5. The siructure weighs $741 \mathrm{lbs}$. and is supported from the cciling with two stecl cables with lengths of $64.5 \mathrm{fl}$. cach. The truss is makle of aluminum struts forming 10 in. cube bays of single lace diagonals alternating so that opmosite faces cross. The batten plane has diagomals which also alicmatc. The major components of the structure are the center scelion $52.5 \mathrm{ft}$. Inng, a $16 \mathrm{ft}$. diameler reflector, and a $9.2 \mathrm{ft}$. Iower where a laser beam is located. The stecl cables are attached to the cnils of two cross memler tuisses $16.7 \mathrm{ft}$. Iong to crisure shability when suspended. Tle actuators alle propurtional librusters using a 12.5 psi rxternal air supply connceted to the moxlel via flexible rubler hoses. A kenal of 8 actuator pairs are placel at four loxations aloug the truss as shown in Fig. 6, and cach acluatur mir is capable of proxlucing 4.4 lbs. In addition, 8 accelerometers arc Iocated with the thrusters for illentification and control experinicnis. The finite element molel has 81 moxles helow 50 117. Because of the suspension, the first six structural moxtes are nendulum moles wilh frequencies between $0.1 \mathrm{H}$., and 0.9 H3. The next three moxles are hending modes with frequencics between $1.4 \mathrm{~Hz}$ and $1.9 \mathrm{H}$. Orthugonal vicws of the mode shanes for mokes 6 through 9 are provided in Figs. 7-10. Control laws are implemented on a digital computer ae sampling rales of $80 \mathrm{~Hz}$ and $3.50 \mathrm{~Hz}$.

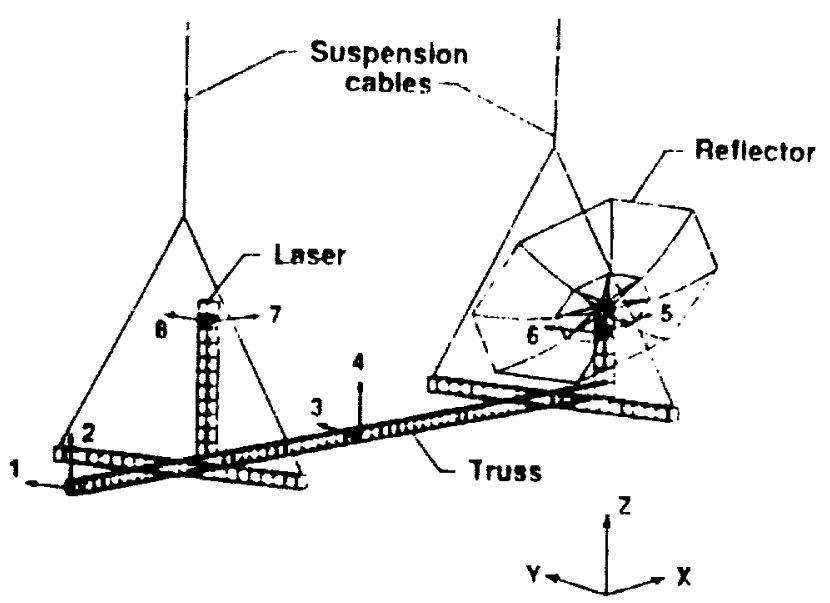

ligure 6. Seliematic of the ('St Findutionary Model slinwing arlualor/sensur loraliens 

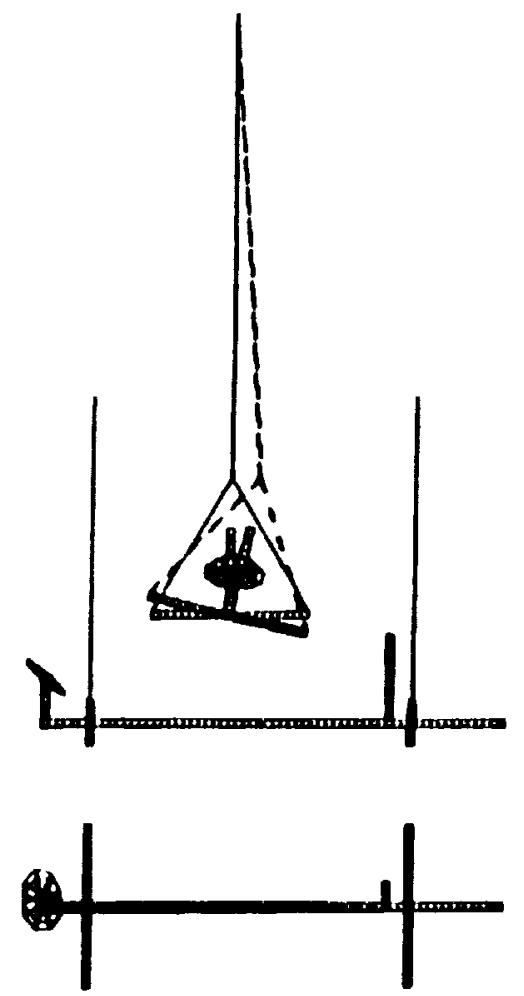

Vigure 7 Vibralion mode 6, r $0.9 \mathrm{ll}$
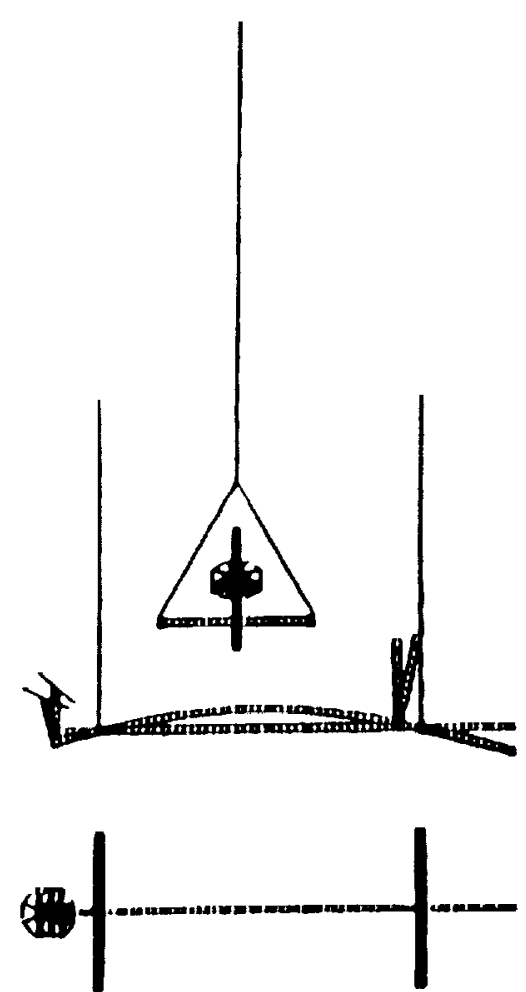

Jigure! Viluration unode: $\mathrm{B}, f=1.7 \mathrm{~Hz}$
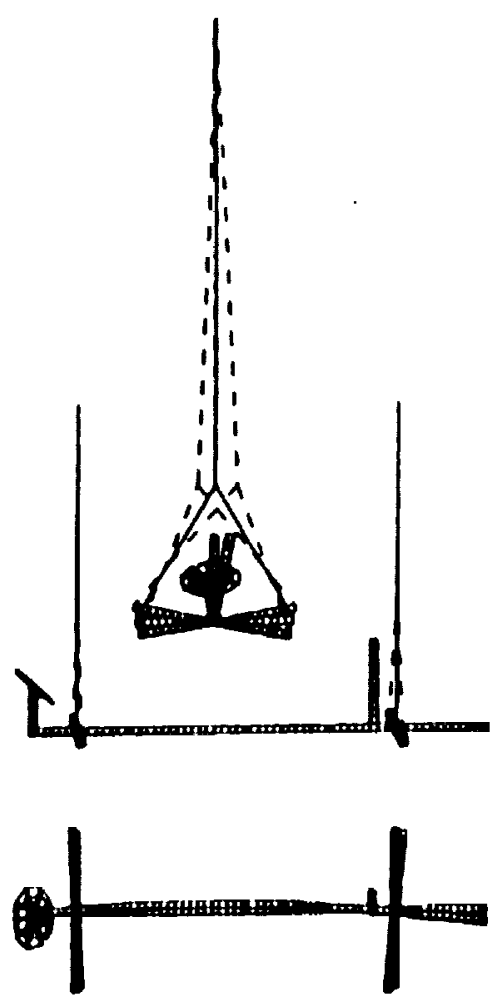

l'igure 8. Viluration mode $7, \mathrm{f}=1.1 \mathrm{II}$
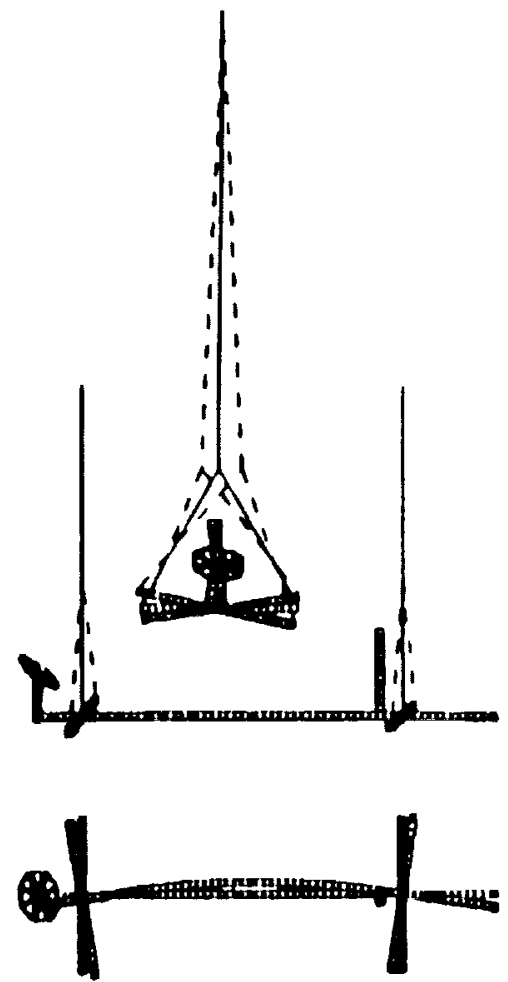

Figure 10. Vilaration mode 9, $f:=1.9$ II 


\section{Controller Degien}

The design theory discussed is now used to develop SISO controllers for exch actuator/sensor pair. The design approach is to detcrnine the most controllahle/obscrvable morte(s) for a particular inpuloutput pair and lune a sceuni unter contmoller to the mode(s). Fanch second order controller has threc design paraneters, namcly, $M_{c}, D_{e}$, and $K_{c}$. If one acluatiof/sensor pair is to control $n$ scpa. rated moxles, $n$ distincl scts of design parameters need in be determined. The proxedure used to design controllers for the cuolutionary moxkl is the following:

(1) Choose $M_{c}$ to avoidl large command offsets.

(2) Chonse a target mole for cach actuator/sensor pair and determine the value of $K_{c}$ neceled to match its frequency, where $K_{c} / M_{c}=\omega^{2}$.

(3) Determine the value of $D_{e}$ which optimizes the damping value of the target morke.

The design objective is to increase damping in the first ninc modes. A value of 0.1 is sclected for $M_{c}$ based on previous experimental results. The moles selected and the corresponding actuator/sensor pair used to contmol them are presented in Table 1. Fach acluator/scnsor location is lilkeled will a mumlker from I to 8 , (sce rig. 6). Using Table 1 , actuator/scensor pair at location 4 is responsible for controlling mode number 8. The actuators at Iocations $1,2,3$, and 7 have two independent controllers for the $1^{\text {ot }}$ ind $2^{\text {nd }}$ target modes, while the remaining four have one.
Allkough the aclualer/sensor at lexation 8 is responsible for mokes 6 and 7, only one controller is designed hy luning its frequency in between the two mostes. To optimize damping, a rool locus is performed for cach actuator/sensor pair by fixing $M_{c}$ and $K_{c}$ and varying $D_{r}$. In Incations where more than one controller is used, each controller is optimized separately. Figure 11 shows the rext keus for mole 6 using actualor/scnsor pair 8 for valucs of $D_{c}$ ranging fmm 0.1 10 1.0. $\wedge$ maximum damping valuc of $3.5 \%$ is achicved when $D_{c}=0.4$. The contmller parameter values, $M_{e}, D_{e}$, and $K_{e}$, for cach sccond order conimller designed are given in Tible 2.

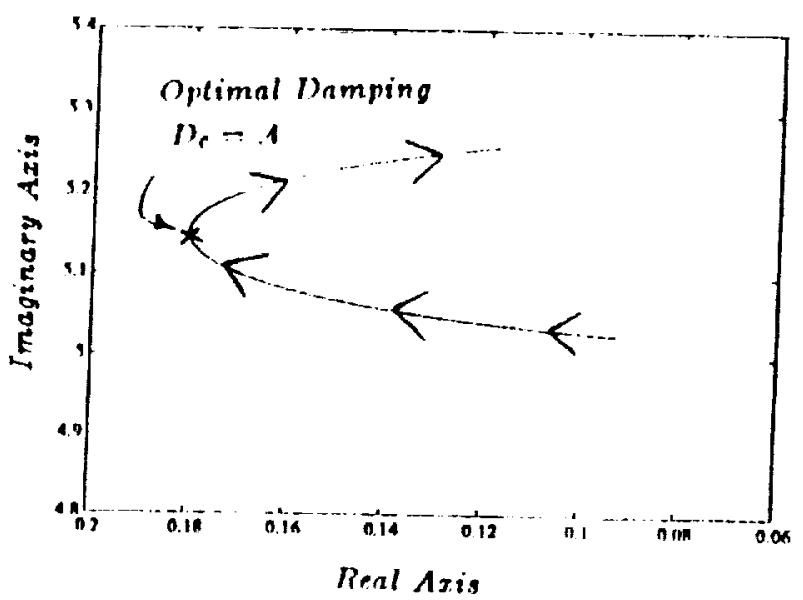

ligure 11 . Mole 6 rout lorus will roulfuller paramMer $I_{c}$

Table 1: Mode number to be controlled and corresponding actuator/sensor location

\begin{tabular}{|c|c|c|}
\hline Localion No. & $1^{\prime \prime}$ Target Mole & $2^{n d}$ Thrget Mode \\
\hline 1 & 3 & 9 \\
\hline 2 & 4 & 8 \\
\hline 3 & 2 & 9 \\
\hline 4 & 8 & - \\
\hline 5 & 1 & - \\
\hline 6 & 3 & - \\
\hline 7 & 1 & 8 \\
\hline 8 & 6 & 7 \\
\hline
\end{tabular}

Table 2: Controller design parameters

\begin{tabular}{|c|c|c|c|c|c|c|}
\hline & \multicolumn{3}{|c|}{$1^{\text {of }}$ Thrget Moxle } & \multicolumn{3}{|c|}{$2^{\text {nd }}$ Target Mole } \\
\hline location & $\boldsymbol{M}_{c}$ & $D_{c}$ & $\boldsymbol{K}_{\varepsilon}$ & $M_{c}$ & $D_{c}$ & $K_{c}$ \\
\hline 1 & .1 & .06 &.$\overline{(089}$ & .1 & .4 & 13.22 \\
\hline 2 & .1 & .2 & 2.10 & .1 & .5 & 10.88 \\
\hline 3 & .1 & .04 & .083 & .1 & .4 & 13.22 \\
\hline 4 & .1 & .4 & 10.88 & - & - & - \\
\hline 5 & .1 & .03 & .083 & - & - & - \\
\hline 6 & .1 & .04 & .083 & - & - & - \\
\hline 7 & .1 & .03 & .08 .3 & .1 & .4 & 10.88 \\
\hline 8 & .1 & .4 & 3.95 & - & - & - \\
\hline
\end{tabular}




\section{Expcrimental Resulte}

\section{Implementation Ingues}

The controllers described in the previous section have special propertics that must be considered in the actual implementation. The active implementation of the AVA controller should ickally cnulate physical spring-mass(iilinjer altakhed to a structure at a single point. This statememt iniplics the critical assumption that collocated scosors and acluators can be realized in the active implementation of the controller. Sensor and actuator collocation must he spatial and tcniporal. Spatial collixation is difficult to achicve Ixecausc of the finite diniensions of sensors and actuators. Typical inounting of scnsors and acluators result in spatially close arrangements, not collocated. Temporal collocation is cven more difficult to achicve. First, the sensors and actuators must have no inherent dynamics in the frequency range zero to infinity. Sccond, the conirol law calculation must proxjuce no phase shift except for that profuced by the AVA controller. Hence, Iemporal collocation can be most closely achicved with very large bandwidth sensors and actuators and analog computations.

In the following paragniphs, the digilal implementalion of the AVA controller will te demonstrated on the struclure shown in Fig. 5. The effects of sample delay, the scquence if real time computilions, and spatial non-collocation are shown using cxperimental data. It should he noted that the sonsors used in this study have a bandwidu of $300 \%$. whereas the actualors have a bandwidili of abxout $45 \mathrm{~Hz}$. In our case, the inaximum frequency to be controlled is at $1.9 \mathrm{I} \%$, and thus, the assumption of negligible sensor and ic tualor dynamics is not goossly violated.

Figure 12 shows the closed-locp intplementation of the system controller. The extemal disturbance r produces the struclural accelcralion oulpul $y$. Switches $A$ and $B$ are used to close the controller loxp. Classic implementation of Kaloman filier based conuollers call for switch $A$ to lxe closed at all limes since the controller is actually an estimalur of the strikiural statcs. It will be shown that lle AVA controlicr is not an estimator and switches $A$ and $1 \mathrm{~b}$ should be closed simultancously to activale closedlexp contuol. When closed-kxop control is activated the following steps take place at cach of the $k^{\text {th }}$ sample pricxls:

(I) Input $y(k)$

(2) Oulpuil u(k)

(3) Compute control force $u(k+1)=C \bar{x}(k)+D y(k)$

(4) Compule controller slates $\tilde{x}(k+1)=\Phi \bar{x}(k)+\Gamma_{y}(k)$

(5) Wail for next clixk pulse

where $\Phi$ and I are the lime discretized versions of the $A$ and Is matrices in Fey. (23). It is also noted that the $D$ matrix for llic AVA controller is null.
The AVA controller has been implemented following the sequence of sicps above at a sample rate of $80 \mathrm{~Hz}$. The struclure was cxcited at two bending modes and Iwo pendulum modes for 10 seconds, then closed-loop control was initiated at 12.5 seconds. Figure 13 shows the accelcration oulput with switch $A$ closed from $I=0$ seconds and implenienting steps $\mathbf{1 . 5}$ above in secpucnes. The controller is unstable in a mode near $7 \mathrm{~Hz}$. Since the AVA controller is not an estimalor, swilch $A$ and $B$ were closed simultancously at $1=12.5$ seconds in the test data of Fig. 14. Even though the controller is still unslable, the initial closed-Iomp accelcration is much improved. This is dice to a smoxth transition from open to closial-l(x)pl. To further improve the closed-kx)p Ixelavior, the controller line delay slemld be reducal. This can be achicvel by climinating the full time step delay that occurs in the computations of steps 1-5 above. Since the $D$ matrix is null, steps 3 and 4 may be reordered to compute the controller state first and then the control force. This climinates the one step delay and results in a stable controller as shown in Fig. 15. Note that it is preferred to scorder the computing scquence instead of substituting the state cquation into the control cquation to eliminate lime delay as the latter results in a $D$ matrix which is not null thus requiring additional computations.

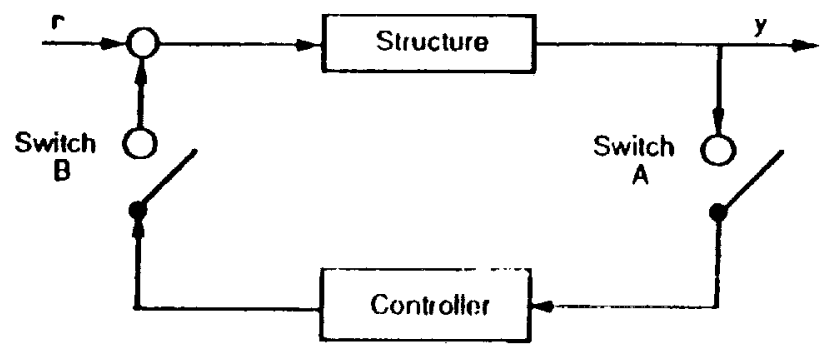

Pigure 12. Conleoller rlosed-loop implenembation

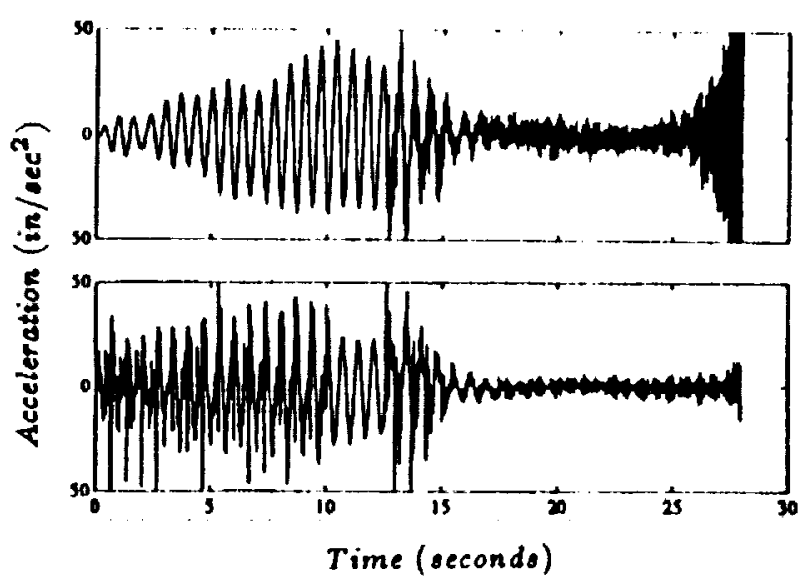

Figure 1.7. (insed loop responses at lorations I and 3 with s witch $A$ closed at $1=0$ 


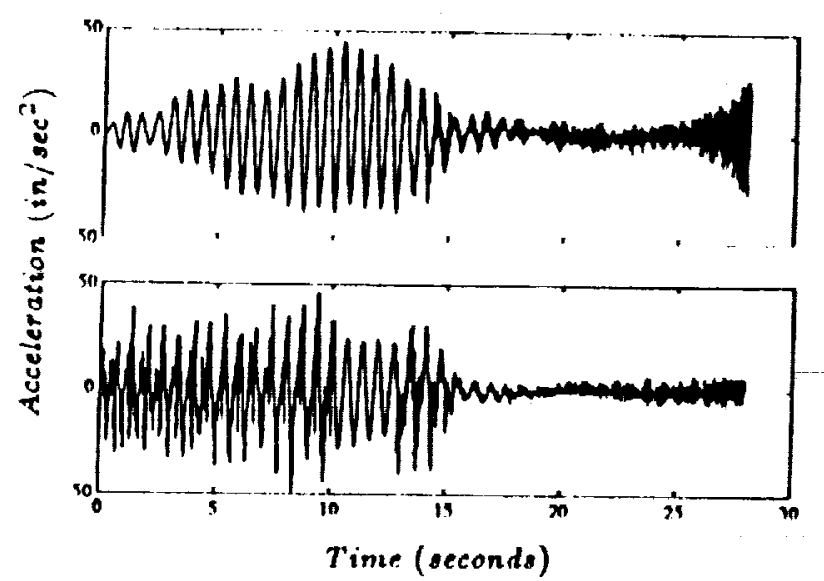

I igure 11. Closed-loop responses at lorations I allel !) with switch $\Lambda$ rlesed al $t=12.5$

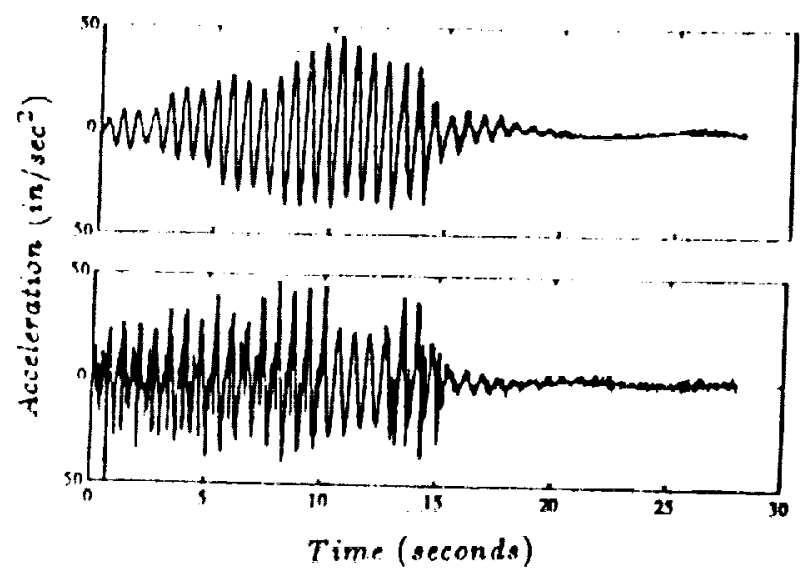

ligure lt. ('Insed lonp responses at locatiens I and I without nne step dolay

Alliongh the combuller is now stable, the response inilicalcs aliasing becilluse of the relatively slow sample rate. When increasing the sample rate, the number of compulallions required to implement the controller is usually a limiting factor. IIence it is Iesirable to limit the size of the controller compulitions. This is ofien kne by controller slate rediction, ox block diagonalization of the $n$ by $n$ stalc matrix using some real transformation. An interesting fiature of the AVA contsoller is its sccond-order stuclure. When transformed to a first order form, the second-order controller equations do not represent $n$ independent states lut rather $n / 2$ independent states. This permits the conliuller rate states to te expressed in terms of controller msilion states. For cxample, a one-step inplicit Irapcooidal inlegration results in the rate states of as functions of the position slates $d$ as:

$$
v(k)=\frac{2}{h}|d(k)-d(k-1)|-v(k-1)
$$

where $h$ is the lime step, $h=t(k)-t(k-1)$. The ahove cquation was used to redixc the controller slate computations for the AVA conimiller which permilted a specd increase from $80 \mathrm{~Hz}$. to $350 \mathrm{~Hz}$, for the 24 stalc, 8 -input 8 oulput contmlkr using a VAXstation $32(x)$ computcr. Figure 16 shows the response of the system for this update rate. Notice the aliasing that eccurred while sampling at $80 \mathrm{~Hz}$ is now absent and that the closed-Ioxp performance is improved.

In Fig. 16 a 32 Itr moxle is being cxcitcd by the controller that was not noliccably excited in the excitation phase. This 32 Hz. moxle has been traced to spatial noncollocation of the sensors and actuators in the original installation. Figure 17 shows the original installation has the actuators (thrusters) mountal in the center of the eruss bay faces, wheress the sensors were mounted on the truss bay comers. Because of this spatial ofrset, torsion-bending coupling of the Iruss vibrations resulted in the closed-Ionp controller exciting a Iorsion mole at $32 \mathrm{H}$.. The sensor installation was moxlificd as shown in Fig. 17 to prevent Ixal torsional bchavior from being sensed.

This modified installation was uscd in the results of Fig. 18. As can be scen, the $32 \%$ mode is no longer being driven by the controller.

In summary, the inplementation of the $\Lambda$ VA contmller using acceleration recilbick is improved by:

(a) Not calculating controller states during the excitation phase

(b) Rescquencing the controlier compule siens to reduce Iclay

(c) Updating the controller as fast as possible

(d) Improving the spatial collocation of scnsors and actuators.

The following section will acscribe the cuntroller nerformance shown in Fig. 18 in more detail.

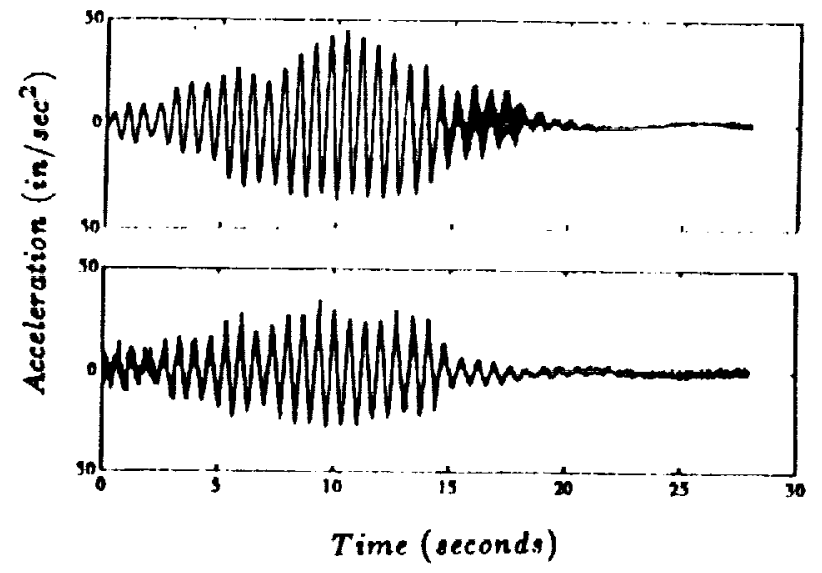

Figure 16. C̈losed-looj responses at localions 1 and 3 with $350 \mathrm{~Hz}$ sample rate. 


\section{Simulation oud Test Comparloon}

In delcrmining the success of AVA controlice, each of the nine moxtes was excited independently, and the controller was then activated for vibration suppression. The top of Fig. 19 shows the experimental open and closel-t(x)p acceleromeier responses for the sixth moxle of the structure. This mode is contmolled from location 8. For open-loop, the structure is excited using sinusoidal excitation at the frequency of the mode of interest for the first 10 seconds. For closed-lomp, the structure is excited in lice same manner, and then the controller is aclivated for the duration of cach test. Shown in the bxttom of Fig. 19 arc the open and closed lowp lime history conjuiter simulntions jerfoninal for the same conditions. Figure 20 depicts the experimental and simulated open and closed-loop responses for the cighth moxle.

Table 3 lists the finite clement and experimental freyuencics, open l l(x)y) damping, predicted closcd loxpp damping, and experimental clesed-loop damping. The experi. mental and analytical frejuencics for the first nine modes are lairly accuratc, but at higher frequencies (not shown), this accuracy decreases considerably. The predicted and aclual damping values achicved when implementing this controller are somewhat different. It is of interest to note that mode 2 showed no damping improvement in the $\mathrm{ex}$ periment. This is due in part to the pendulum mode accelcration lxing nearly equal and opposite to the geometric change in accelcration due 10 gravily. Since the finite clcinent model of the structure docs mot incluck gravity. the cxperimentally sensed acceleration for this moxle is significantly lower than prediclal. Although the damping obtained with use AVA controller is not predicted well, stability is conserved under modeling crrors.

Origrial Inslaltidion

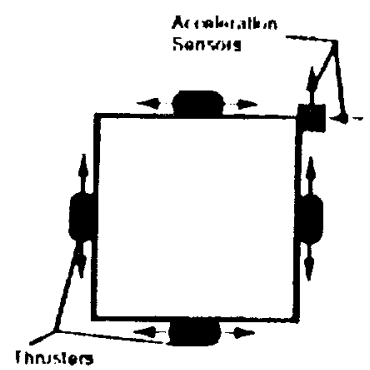

Modtied lestallatlon

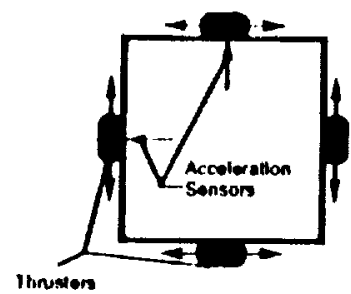

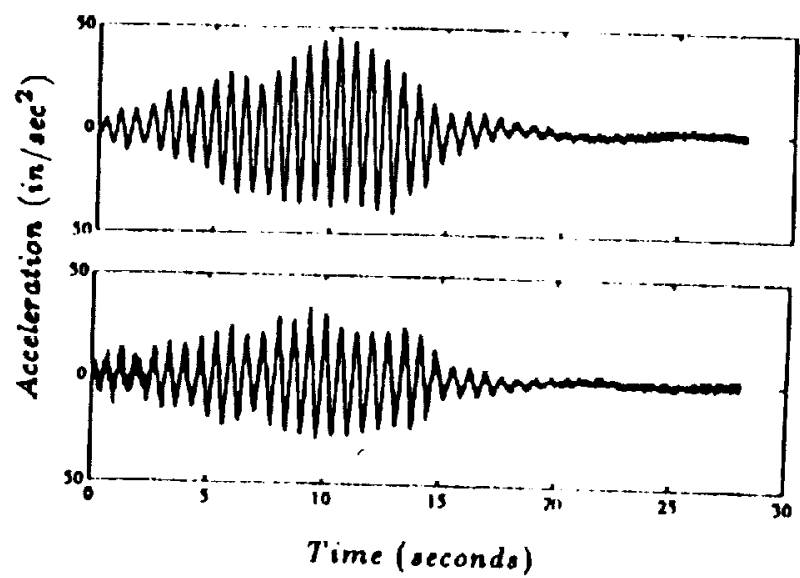

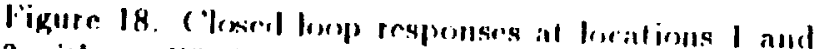
3 will morodilied sensor iustalliation

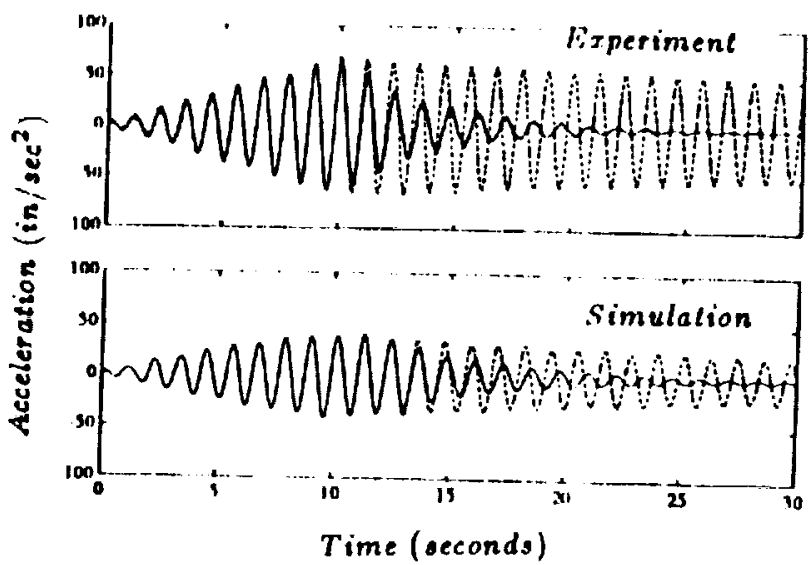

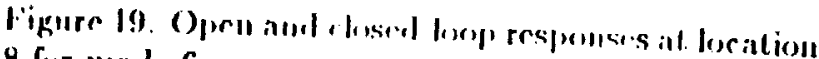
8 for mode 6

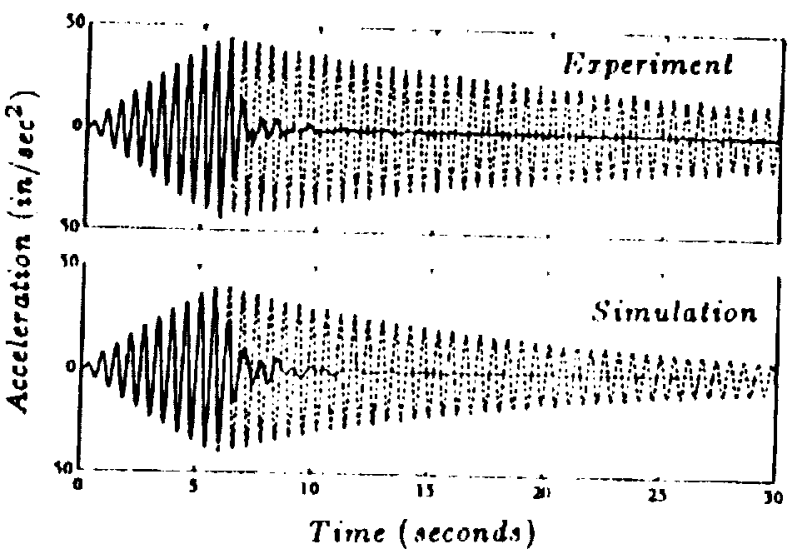

Figure 20. Open and closed kopp respouses at location 2 for mode 8

Pignure 17. 'Testlued siensor/artualer installation 
Thble 3: Comparison of Experimental and Analytical Frequency and Damping Results

\begin{tabular}{|c|c|c|c|c|c|}
\hline \multirow{2}{*}{$\begin{array}{c}\text { Mode } \\
\text { Number }\end{array}$} & \multicolumn{2}{|c|}{ Frequency (17) } & \multicolumn{3}{|c|}{ Damping (3) } \\
\cline { 2 - 6 } & Analysis & Experiment & $\begin{array}{c}\text { Experiment } \\
\text { Open-loop }\end{array}$ & $\begin{array}{c}\text { Analysis } \\
\text { Closed-loop }\end{array}$ & $\begin{array}{c}\text { Experiment } \\
\text { Closed-loop }\end{array}$ \\
\hline 1 & .146 & .14 & 4.7 & 8.7 & 10.6 \\
2 & .148 & .14 & 7.0 & 10.9 & 6.8 \\
3 & .154 & .15 & 7.0 & 13.0 & 13.5 \\
4 & .720 & .73 & 1.5 & 1.5 & 8.2 \\
5 & .741 & .72 & 1.2 & 6.5 & 6.2 \\
6 & .868 & .90 & .6 & 3.7 & 4.7 \\
7 & 1.43 & 1.50 & .4 & 4.6 & 9.3 \\
8 & 1.66 & 1.72 & .66 & 7.8 & 13.1 \\
9 & 1.83 & 1.90 & .50 & 4.8 & 8.0 \\
\hline
\end{tabular}

\section{Conclusions}

The implementation of the active vibrat ion absorher has been experimentally demonstrated. Using only acceleration fecdback, a second order controller design is presented which represents an active luned spring-mass-damper assembly. Experiment and simulation results show the controller performs well even in the presence of modeling errors. Since acceleration sensors are relatively inexpensive and provide an incrial measurement, this type of sensor is likely to be used in structural control applications. The controller design presented herein permits direct use of accelcration signals without the necd for prefiltering. Morcover, the active vibration absorber has high stability mbustness as only its perfonnance, not its stability, is model-based. General implementation issues are discussed to insure the reader can properly use this technology in other applications. The effects of porr implementation are shown using experimental dala. With proper implementation, the $\mathrm{con}$ troller successfully angments the damping of the struclure. This simple controller design, due to its high level of siahility mbustness, has grent potential for distributed, innerand outer-loop control systems for spacecraft stnuclures.

\section{References}

(I) Benhabid, R.J. Flashner, II.K., andl Ting, F.C., "ACOSS Fourtecn (Active Control of Space Structures)," RADC. TR-83-51, Final Repon, March 1983.

(2) Irwin. R.D.Jones, V.L., Rice, S.A. Tollison, D.K., and Seltzer, S.M., "Active Control Technique Evaluation for Spacecralt (ACES)", Final Report Aug. 1986-July 1987, AFWAL-TR-88-3038.

[3] Tanner, S., Pappa, R., Sulla, J., Elliott, K., Miserentino, B., Bailey, J., Conper, P., Williams, B., "Mini-Mast CSI Testbed Uscr's Guide," NASA TM-102630, Langley Rescarch Center, Fchruary 1991.

[4] Belvin, W. K., Elliou, K., Bruner, A., Sulla, J. and Bailey, J." "The LaRC CSI Phase-0 Evolutionary Model Testbed: Design and Experimental Results," presented at the 4th Annual NASA/DOD Conference on Control/ Structures Intcraction Techmology, Nov. 1990.

[5] Juang, J.-N. and Phan, M., "Robust Controller Designs for Socond-Order Dynamic Sysicms: A Virtual Passive Approach," NASA TM-102666, Langley Rescarch Center, May 1990.

[6] Snowdon, J.C.. Vilbratlon and Shock In Damped Mrehanieal Syatemn, John Wilcy \& Sons,lic., New York 1968. 


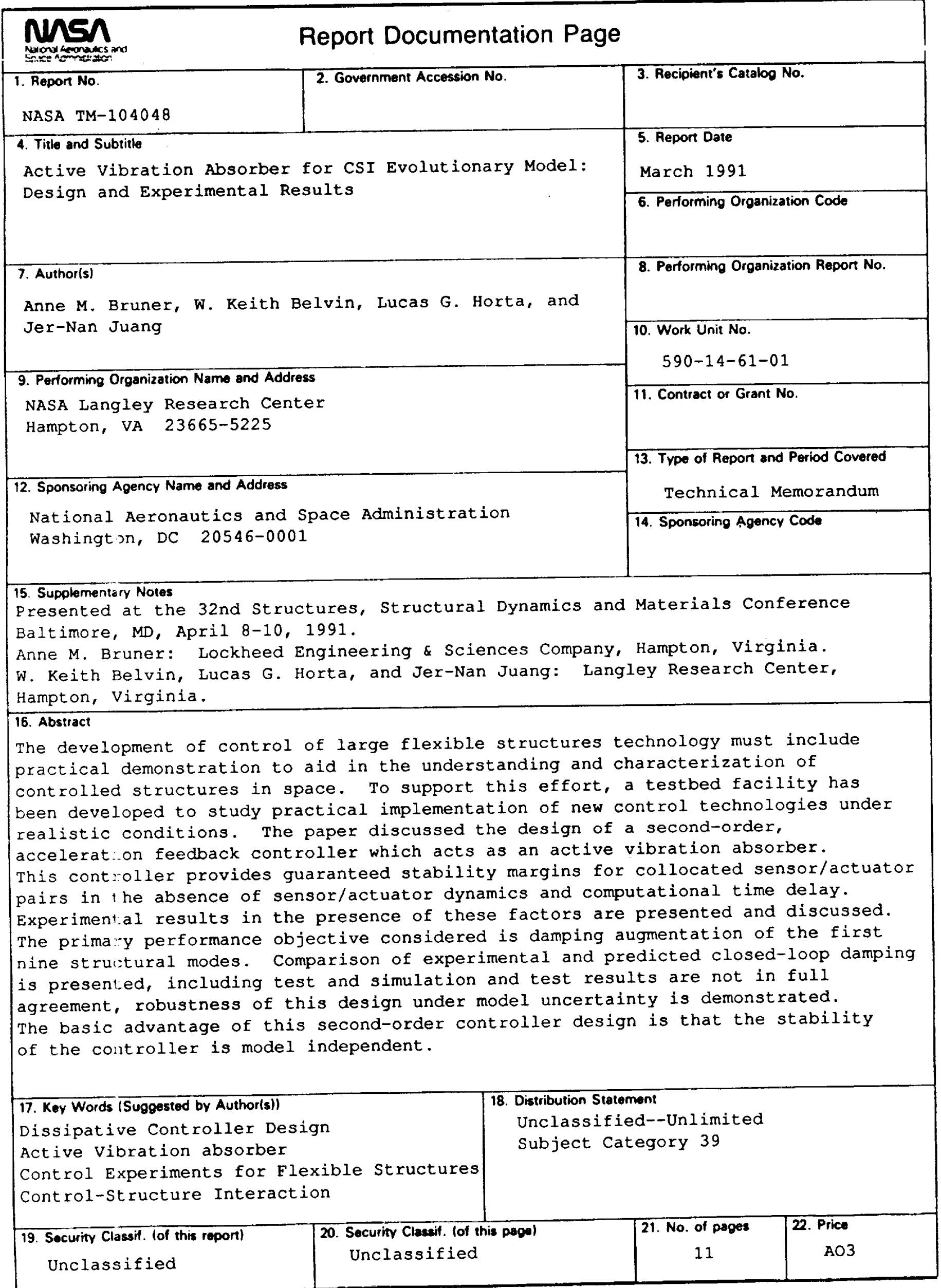


